\title{
Regulation by low temperature of phytoplankton growth and nutrient uptake in the Southern Ocean
}

\author{
David S. Reay ${ }^{1}$, Julian Priddle ${ }^{2}$, David B. Nedwell ${ }^{1, *}$, Michael J. Whitehouse ${ }^{2}$, \\ J. Cynan Ellis-Evans ${ }^{2}$, Clare Deubert ${ }^{1}$, Douglas P. Connelly ${ }^{3}$
}

\author{
${ }^{1}$ Department of Biological Sciences, University of Essex, Wivenhoe Park, Colchester CO4 3SQ, United Kingdom \\ ${ }^{2}$ British Antarctic Survey, Natural Environment Research Council, High Cross, Madingley Road, Cambridge CB3 0ET, \\ United Kingdom \\ ${ }^{3}$ Southampton Oceanography Institute, University of Southampton, Waterfront Campus, European Way, \\ Southampton SO14 3ZH, United Kingdom
}

\begin{abstract}
During oceanographic cruises in 1996 and 1998, phytoplankton from 15 stations in the southwest Atlantic sector of the Southern Ocean were incubated at ambient temperature and 2 elevated temperatures (ambient plus $3^{\circ} \mathrm{C}$, and ambient plus $6^{\circ} \mathrm{C}$ ). Rates of growth, nutrient depletion, ${ }^{15} \mathrm{~N}$-nitrate uptake and nutrient interaction were all studied. Microalgal growth rate showed a strong positive relationship to temperature elevation, indicating ambient temperatures were sub-optimal for the phytoplanktonic community as a whole. Ratios of silicate uptake to chlorophyll a increase were high at ambient temperatures and showed a strong negative relationship with temperature elevation. Nitrate uptake rates, measured by ${ }^{15} \mathrm{~N}$-nitrate incorporation, showed a consistent trend of increased uptake rate at elevated temperature. Specific nitrate-depletion rates, ${ }^{15} \mathrm{~N}$-nitrate uptake rates, and the $f$ ratio all showed an inverse relationship to increasing ammonium concentration. The results of this study imply that ambient temperature, in addition to direct iron limitation, is important in the maintenance of the high nutrient, low chlorophyll conditions common to the Southern Ocean.
\end{abstract}

KEY WORDS: Nitrate · Ammonium · Iron · Limitation · Inhibition · HNLC regions Resale or republication not permitted without written consent of the publisher

\section{INTRODUCTION}

Over the past 30 yr interest has increased in oceanic areas which exhibit the apparent paradox of yearround abundant macronutrients (e.g. nitrate, phosphate and silicate), but low chlorophyll and low primary productivity (e.g. Dugdale \& Goering 1967 , Barber et al. 1971, DeBaar 1990, Wheeler \& Kokkinakis 1990, Chisholm \& Morel 1991, Cullen 1991). These regions are commonly denoted 'high nutrient, low chlorophyll' (HNLC) areas (Minas et al. 1986), and potentially represent areas of increased primary production, and enhanced $\mathrm{CO}_{2}$ drawdown, if changed environmental conditions favour increased phyto-

*Corresponding author. E-mail: nedwd@essex.ac.uk plankton growth (Sarmiento \& Orr 1991, Priddle et al. 1992). The Southern Ocean is the largest and potentially the most important of these regions. Understanding the factors which produce and maintain its status as an HNLC region is crucial when constructing a global carbon budget and predicting the effects of environmental change (Joos et al. 1991).

The importance of iron limitation in the Southern Ocean HNLC area was first suggested by Hart (1934), and put into a more global context by Martin et al. (1990). More recent iron addition experiments in the equatorial and sub-Arctic Pacific HNLC regions have underlined the potential for increased primary production and $\mathrm{CO}_{2}$ drawdown in HNLC areas (e.g. Price et al. 1991, Behrenfeld et al. 1996, Frost 1996, Turner et al. 1996). Iron addition experiments in the Southern Ocean HNLC region have produced similar results 
(e.g. Scharek et al. 1997, VanLeeuwe et al. 1997, Sedwick et al. 1999). Although in some areas iron concentrations appear to be above limiting levels (Buma et al. 1991, Basterretxea \& Aristegui 1999), the importance of iron limitation in the Southern Ocean as a whole is clear (DeBaar et al. 1995). However, this should not distract from the existence of other factors contributing to the maintenance of HNLC conditions in the Southern Ocean (see Chisholm \& Morel 1991, Boyd et al. 1999, Bracher et al. 1999). As well as iron limitation, environmental temperature may also play an important role in limiting nutrient drawdown and net primary production in this region (Tilzer et al. 1986, Priscu et al. 1989). Such a role may be particularly important when considered in the context of subtle changes in temperature arising from global warming.

In the Southern Ocean, surface water temperatures reach as low as $-1.8^{\circ} \mathrm{C}$, with a maximum summer temperature of around $4.0^{\circ} \mathrm{C}$ (Herbert \& Bhakoo 1979). It is increasingly accepted that the majority of oceanic phytoplankton in the Southern Ocean are psychrotolerant, rather than psychrophilic, with temperature optima for growth and photosynthesis far in excess of any environmental temperature encountered (Tilzer et al. 1986, Smith \& Harrison 1991). Reduced photosynthetic capacity in phytoplankton and reduced affinity for organic substrates by bacteria at low temperatures have already been demonstrated ( $\mathrm{Li}$ et al. 1984, Li 1985, Nedwell \& Rutter 1994). In low-temperature environments, active uptake of inorganic nutrients such as nitrate, silicate and, in particular iron, may also be reduced.

Several studies have reported a strong temperaturedependence of nitrate reductase activity and hence nitrate assimilation in algae (e.g. Tischner \& Lorenzen 1981, Gao et al. 1993). Limitation of nitrate transport in the freshwater cyanobacterium Synechococcus sp. by low temperature has also been well documented (Sakamoto \& Bryant 1997, 1998, 1999). Similarly, in a previous laboratory study, we have demonstrated that the specific affinity of a range of bacteria and marine microalgae for nitrate is significantly reduced at suboptimal temperatures (Reay et al. 1999). Indeed, low affinity for inorganic nutrients, indicated by a high half-saturation constant $\left(K_{s}\right)$ for uptake of both silicate and nitrate, has already been reported for Southern Ocean phytoplankton at low temperatures (Jacques 1983, Sommer 1986). The exact mechanism responsible for, and temperature dependence of, iron uptake in marine algae and bacteria remains undefined. However, work on iron reduction and assimilation in Saccharomyces cerevisiae indicates an active, NADPHdependent process (Lesuisse et al. 1991, 1998, Anderson et al. 1992), which might also be expected to exhibit temperature-dependence.
Here, we investigate the effects of elevated temperature on growth and inorganic nutrient uptake by natural populations of Southern Ocean phytoplankton collected around the Subantarctic island of South Georgia.

\section{MATERIALS AND METHODS}

The study was carried out on British Antarctic Survey Cruises JR11 and JR38 aboard the RRS 'James Clark Ross' in January-February 1996 and DecemberJanuary 1998/99 respectively. The study area comprised both deep-sea and shelf waters to the north of South Georgia, a large Subantarctic island in the northern Scotia Sea. South Georgia is located between 54 and $55^{\circ} \mathrm{S}$ latitude, and is situated south and east of the Polar Front, as the Antarctic Circumpolar Current trends to the northwest of the island before resuming an easterly course. Samples were taken at a total of 15 stations encompassing an area running from north of the Polar Front $\left(51^{\circ} \mathrm{S}\right)$ down to the shelf waters of South Georgia (Fig. 1). Three of the sampling stations $(1,5$ and A) were situated north of the Polar Front. More detailed information on the study area can be found in Priddle et al. (1997).

Sampling protocol, nutrient and chlorophyll analyses. Bulk water samples (20 l) were collected from 30 to $40 \mathrm{~m}$ depth using a General Oceanics water-bottle rosette system mounted on a Neil Brown Mark 3 CTD.

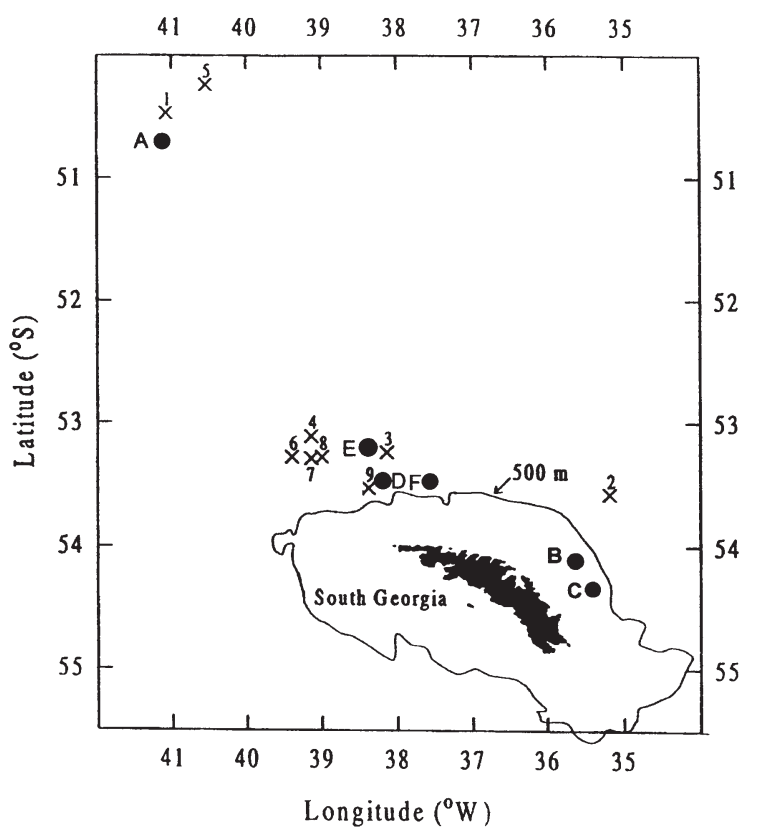

Fig. 1. Site map of sample stations around Georgia. X: stations on Cruise JR11 (1996). •: stations on Cruise JR38 (1998/99) 
Triplicate sub-samples $(30 \mathrm{ml})$ were taken from the 201 bulk sample. These time-zero sub-samples were filtered (Whatman GF/F: nominal particle retention $0.7 \mu \mathrm{m})$ and analysed colorimetrically for dissolved nitrate $\left(\mathrm{NO}_{3}^{-}\right)$, nitrite $\left(\mathrm{NO}_{2}^{-}\right)$, ammonium $\left(\mathrm{NH}_{4}{ }^{+}\right)$, phosphate $\left(\mathrm{PO}_{4}{ }^{2-}\right)$ and silicate $\left(\mathrm{Si}(\mathrm{OH})_{4}\right)$, using a segmented flow auto-analyser. Precision was better than $\pm 1 \%$ for all analyses, and nutrient concentrations did not fall below minimum detection levels (Whitehouse \& Woodley 1987). On 3 occasions, control samples of ultra high-purity water (UHP) were also filtered and analysed to check for any contamination caused by filtration and sample processing.

For nutrient depletion experiments on Cruise JR11, duplicate sub-samples of 100 to $400 \mathrm{ml}$ were taken from the initial 201 water sample and filtered (Whatman GF/F). Filters were extracted in 90\% v:v acetone:water (HPLC grade: Rathburn Chemicals Ltd, Walkerburn, UK) in the dark at approximately $2{ }^{\circ} \mathrm{C}$ for $24 \mathrm{~h}$ for chlorophyll a ( $\mathrm{chl}$ a) and phaeopigment analysis. Fluorescence was measured before and after acidification using a Sequoia-Turner Model 112 benchtop fluorometer. Chl a extracted from the cyanobacterium Anacystis nidulans (Sigma Chemical Company) provided a standard for calibration of the fluorometer, and the standard solution itself was calibrated spectrophotometrically (Parsons et al. 1984).

The temperatures of 3 large water baths containing roller beds were set to give incubation temperatures of 3 and $6^{\circ} \mathrm{C}$ above ambient, together with a control at ambient temperature. Incubation temperatures were controlled by thermo-circulators (Conair-Churchill Ltd, Uxbridge, Middlesex, England) which gave control to $\pm 0.1^{\circ} \mathrm{C}$. Nine clear-glass Duran bottles $(620 \mathrm{ml})$ were prepared for each incubator, 3 bottles being covered in black plastic to exclude light. Samples were incubated under constant illumination $\left(200 \mu \mathrm{mol} \mathrm{m} \mathrm{m}^{-2}\right.$ $\mathrm{s}^{-1}$ ) and at a constant rotation rate $(70 \mathrm{rpm})$ for $72 \mathrm{~h}$ to maintain plankton in suspension. Illumination was provided by a bank of fluorescent tubes (Triton $38 \mathrm{~W}$, 400 to $710 \mathrm{~nm}$ [Peaks 450, 550 and $620 \mathrm{~nm}$ ], Interpet Ltd, Dorking, UK) suspended directly above each incubator. Temperature and light levels in each incubator were recorded daily. Sub-samples $(30 \mathrm{ml})$ were removed from each bottle at $12 \mathrm{~h}$ intervals, filtered (GF/F), and analyzed immediately for nutrients. After a $72 \mathrm{~h}$ incubation period, final sub-samples were removed for nutrient analyses and a 100 to $300 \mathrm{ml} \mathrm{sam-}$ ple was taken from each bottle and filtered (GF/F). These filters were then extracted for chl a analysis as described previously.

Experimental protocol for nutrient-depletion experiments in the second part of Cruise JR11 (Stns 4, 5 and 6) was identical to that described above. However, filtered water samples for nutrient analysis were pre- served with $\mathrm{HgCl}_{2}\left(20 \mu \mathrm{g} \mathrm{ml}^{-1}\right)$ and stored at $2{ }^{\circ} \mathrm{C}$ until analysis in the UK (Kirkwood 1996). Chl a samples were collected by the previously described method, but filters were then frozen at $-20^{\circ} \mathrm{C}$ until acetone extraction and fluorometric measurement of chl a concentration was undertaken in the UK. At Stn 6, the above protocol was used (Stn 6a), together with a parallel set of incubations where sufficient $\mathrm{NH}_{4} \mathrm{Cl}$ was added to give an increase of approximately $1 \mathrm{mmol} \mathrm{m}^{-3}$ above the ambient concentration (Stn 6b).

${ }^{15} \mathrm{~N}$-labeled nitrate uptake experiments. Methods for ${ }^{15} \mathrm{~N}$-nitrate uptake experiments were identical on both cruises unless otherwise noted. A 201 water sample was collected as described previously, and subsamples were taken immediately for nutrient and chl a analysis. An addition of $\mathrm{Na}^{15} \mathrm{NO}_{3}$ (99.6 at. \%) was made to the water sample, to give approximately $10 \%$ enrichment above ambient concentrations, and further sub-samples for nutrient analyses were taken. The temperatures of the 3 water baths were again set to give incubation temperatures of 3 and $6^{\circ} \mathrm{C}$ above ambient, together with an ambient control. For Cruise JR11 each water bath contained four $620 \mathrm{ml}$ bottles, 3 clear and 1 blacked out, and these were filled completely with the ${ }^{15} \mathrm{~N}$-nitrate-labeled sample water. For incubations on Cruise JR38, sets of triplicate bottles were also spiked with either an ammonium addition equivalent to an elevation of $1 \mathrm{mmol} \mathrm{m}^{-3}$, or $\mathrm{FeSO}_{4}$ equivalent to a $10 \mu \mathrm{mol} \mathrm{m} \mathrm{m}^{-3}$ elevation, a putative saturating concentration.

Bottles were incubated under constant illumination for $24 \mathrm{~h}$, after which a triplicate sub-sample of 100 to $200 \mathrm{ml}$ was taken from each bottle. Sub-samples were filtered onto aluminium oxide filters (Whatman Anodisc 25: nominal particle retention $0.2 \mu \mathrm{m}$ ) either directly, or after pre-screening through a cellulose acetate filter (Whatman Grade 4: nominal particle retention $20 \mu \mathrm{m})$. Filters were then frozen at $-20^{\circ} \mathrm{C}$ and later dried at $50^{\circ} \mathrm{C}$ for analysis. Isotope and total nitrogen analysis of filters were undertaken in the UK using a Roboprep-CN elemental analyzer coupled to a Tracermass mass spectrometer (Barrie \& Prosser 1996) at the NERC stable-isotope facility, ITE Merlewood, Cumbria, by Mr Chris Quarmby.

Iron analysis. A limited number of water samples were also taken both immediately after collection $(\mathrm{n}=4)$ at Stns A and D on Cruise JR38, and after $48 \mathrm{~h}$ under standard incubation conditions $(n=4)$ for subsequent iron analysis. These water samples were collected into acid-washed low-density polyethylene bottles under a laminar flow hood to prevent particulate iron contamination. Iron analyses were carried out in the UK at the Southampton Oceanography Centre. Dissolved iron in the samples was separated and preconcentrated from the seawater using a chelation and 


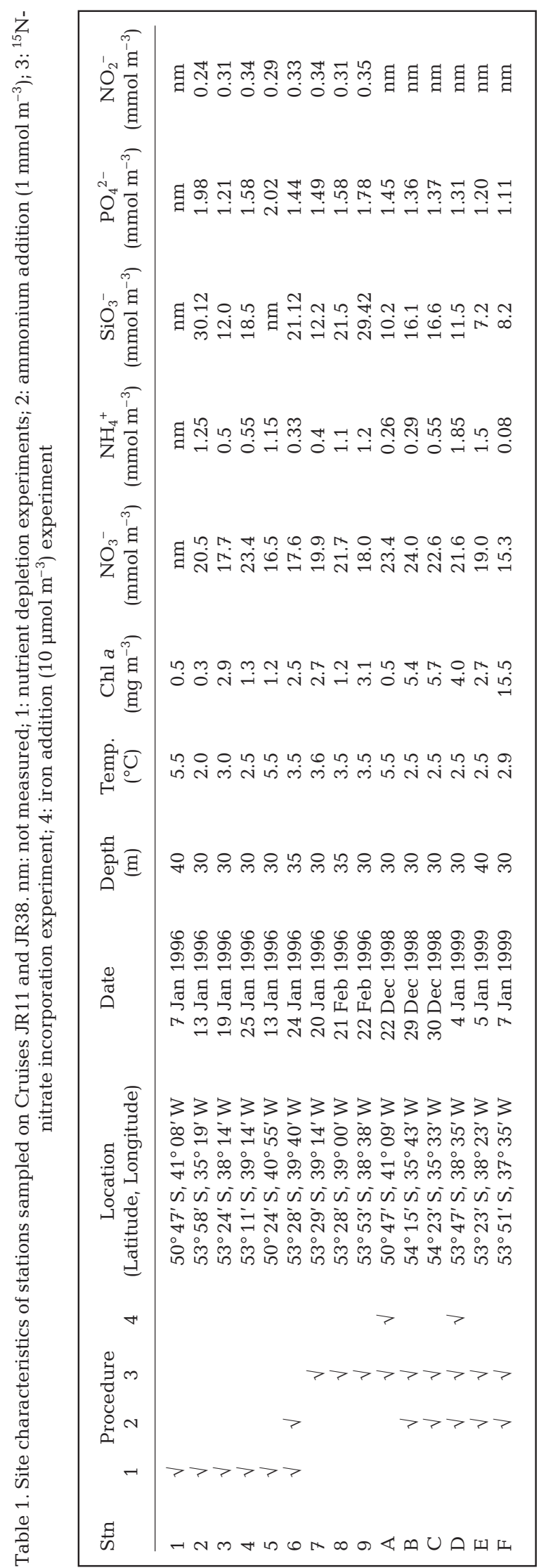

solvent-extracted procedure based on established procedures (Bruland et al. 1979, Statham 1985). Dissolved metals in samples were complexed with a mixed dithiocarbonate reagent and the complexes extracted from the seawater into chloroform. The chloroform extracts were reduced to dryness in a clean bench, and the residue was oxidized with concentrated nitric acid. The oxidized residue was dissolved in a small volume of dilute nitric acid and the metals in this final extract were determined by graphite furnace atomic-absorption spectrophotometry. Analytical quality-control procedures used analysis of a certified reference material (CRM, NASS-2, CRCC), which showed good agreement between measured and quoted CRM values. Iron analyses represent minimum concentrations, as any iron adsorbed into bottle walls was excluded, although the use of acid-washed Go-Flo bottles should have minimized such losses.

Data analysis. Relationships between data were examined by 1 -factor and 2 -factor analysis of variance (ANOVA), with post-hoc Tukey tests where appropriate, by using linear least-squares regression analysis (LRA), and by Spearman's rank correlation (SRC). Data were log-transformed where assumptions of normality and variance homogeneity were not met. Statistical analysis and plots of data were undertaken using the data analysis packages supplied in Systat, Version 7.0 (SPSS Inc., Richmond, USA) and in Sigma Plot, Version 5.0 (SPSS).

\section{RESULTS}

\section{Temperature, chlorophyll and nutrient concentrations}

Mean surface water temperatures (30-40 m) ranged from 2 to $5.5^{\circ} \mathrm{C}$ over the course of the 2 cruises (Table 1) and concentrations of chl a were relatively low at all stations. Only Stn F on the second cruise (JR38) showed $\mathrm{chl}$ a concentrations approximating to bloom conditions, although chl a concentrations at Stns B, C and D were also high for the Scotia Sea. No significant relationship (LRA, $p>0.1$ ) between in situ temperature and chl $a$ or nutrient concentration was evident. Nitrate and phosphate concentrations at all stations were high for oceanic waters, but concentrations of all nutrients were in the range reported previously for this region (Whitehouse et al. 1996). Ambient nutrient concentrations generally showed an inverse relationship with concentrations of chl $a$. Concentrations of all measured nutrients were considerably lower at Stn F compared to all others, with ammonium concentrations bordering on undetectable $\left(<0.01 \mathrm{mmol} \mathrm{m}^{-3}\right)$. Where examined (Stns 7, 8 and 9), the phytoplanktonic assemblage was 
dominated by the $<20 \mu \mathrm{m}$ size fraction, although microscopic examination showed the haptophyte Phaeocystis sp. to be very common at Stns 4,5 and 6. Nitrite concentrations were low and invariable throughout the study, and are not considered further here.

\section{Growth rate and nutrient uptake}

Microalgal growth, as calculated from increases in chl a over $72 \mathrm{~h}$, demonstrated a difference in both growth rate and its degree of response to temperature elevation between stations. Temperature increases of both 3 and $6^{\circ} \mathrm{C}$ above ambient had a highly significant (ANOVA, Tukey $\mathrm{p}<0.01$ ) positive effect on growth rate compared to that at ambient temperature across Stns 1 to 6 (Fig. 2), the growth rate doubling or even tripling at elevated temperatures. Little or no net algal growth was observed in blacked-out bottles, chl a concentrations generally falling slightly over the course of experiments (Table 2). Previous studies (e.g. Geider et al. 1997) have indicated that the ratio of chl a to biomass tends to increase with elevated temperature. Such an effect may therefore overestimate the actual increase in growth rate brought about by temperature elevation. The possibility of uncoupling of chl a synthesis with biomass accumulation was examined by plotting the increase in chl a against the decrease in inorganic nitrogen (Fig. 3). Data for the ammonium addition experiment at Stn 6 are also included (Stn 6b). The ratio of chl a produced to nitrogen utilized ( $\mathrm{g}: \mathrm{mol})$, when all data were considered, was $0.9 \pm 0.11( \pm \mathrm{SE}$,

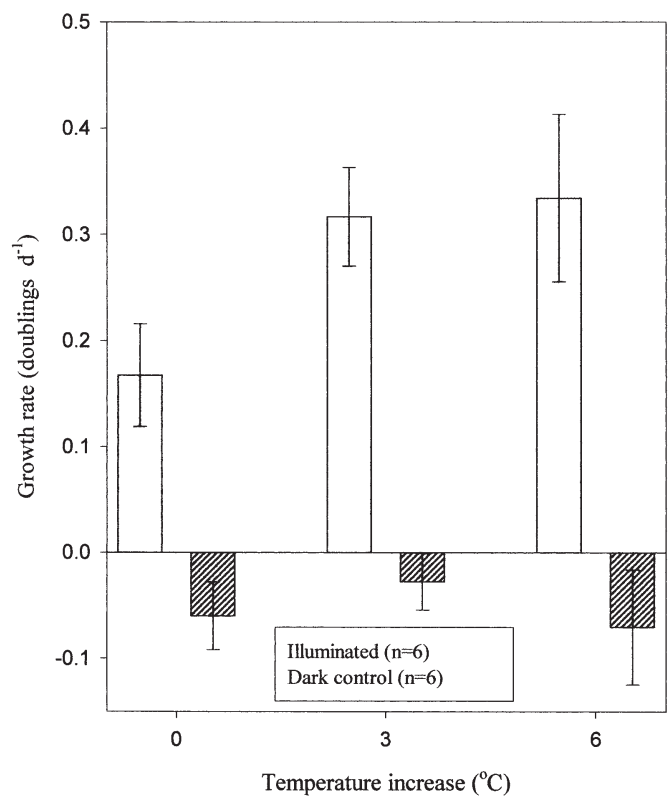

Fig. 2. Changes in microalga growth rate with increasing temperature. Data are mean $( \pm$ SE) growth rates from 6 stations on Cruise JR11

Table 2. Mean $( \pm \mathrm{SE})$ changes in chlorophyll a $(\mathrm{chl}$ a) concentration, growth rate and uptake ratios with temperature elevation and station on Cruise JR11 in light $(\mathrm{n}=6)$ and dark $(\mathrm{n}=3)$. All data are derived from $72 \mathrm{~h}$ incubations. Si:chl $a=\mathrm{Si}$ : silicic acid used: chl a produced; $\mathrm{Si}: \mathrm{N}=$ silicic acid used:nitrate used; na = not available; $\mathrm{nN}=$ no net nitrate depletion

\begin{tabular}{|c|c|c|c|c|c|c|c|}
\hline \multirow[t]{2}{*}{ Stn } & \multirow{2}{*}{$\begin{array}{c}\text { Temp. } \\
\left({ }^{\circ} \mathrm{C}\right)\end{array}$} & \multicolumn{2}{|c|}{$\mathrm{Chl} \mathrm{a}\left(\mathrm{mg} \mathrm{m}^{-3}\right)$} & \multicolumn{2}{|c|}{ Growth rate $\left(\mathrm{d}^{-1}\right)$} & \multirow{2}{*}{$\begin{array}{l}\text { Si:chl a } \\
\text { (mol:g) }\end{array}$} & \multirow{2}{*}{$\begin{array}{c}\mathrm{Si}: \mathrm{N} \\
(\mathrm{mol}: \mathrm{mol})\end{array}$} \\
\hline & & Light & Dark & Light & Dark & & \\
\hline \multirow[t]{3}{*}{1} & 5.5 & $1.79 \pm 0.05$ & $0.32 \pm 0.05$ & $0.86 \pm 0.024$ & $-0.12 \pm 0.019$ & na & na \\
\hline & 8.5 & $2.2 \pm 0.11$ & $0.39 \pm 0.01$ & $1.13 \pm 0.057$ & $-0.07 \pm 0.002$ & na & na \\
\hline & 11.5 & $2.2 \pm 0.12$ & $0.24 \pm 0.03$ & $1.13 \pm 0.062$ & $-0.17 \pm 0.022$ & na & na \\
\hline \multirow[t]{3}{*}{2} & 2 & $0.79 \pm 0.04$ & $0.29 \pm 0.04$ & $0.54 \pm 0.028$ & $-0.01 \pm 0.002$ & 1.5 & $\mathrm{nN}$ \\
\hline & 5 & $1.36 \pm 0.06$ & $0.29 \pm 0.03$ & $1.18 \pm 0.052$ & $-0.01 \pm 0.001$ & 0.68 & $\mathrm{nN}$ \\
\hline & 8 & $2.65 \pm 0.29$ & $0.36 \pm 0.04$ & $2.61 \pm 0.286$ & $0.07 \pm 0.007$ & 0.49 & 2.3 \\
\hline \multirow[t]{3}{*}{3} & 3 & $4.15 \pm 0.41$ & $2.68 \pm 0.51$ & $0.14 \pm 0.014$ & $-0.03 \pm 0.005$ & 5.8 & 1.3 \\
\hline & 6 & $7.55 \pm 0.75$ & $2.39 \pm 0.10$ & $0.53 \pm 0.053$ & $-0.06 \pm 0.002$ & 1.4 & 1.1 \\
\hline & 9 & $8.86 \pm 0.60$ & $2.51 \pm 0.61$ & $0.69 \pm 0.046$ & $-0.04 \pm 0.011$ & 1.1 & 1.0 \\
\hline \multirow[t]{3}{*}{4} & 2.5 & $1.7 \pm 0.1$ & $1.2 \pm 0.1$ & $0.10 \pm 0.006$ & $-0.03 \pm 0.002$ & 10.4 & 0.7 \\
\hline & 5.5 & $3.8 \pm 0.2$ & $1.5 \pm 0.1$ & $0.64 \pm 0.034$ & $0.05 \pm 0.003$ & 1.7 & 0.8 \\
\hline & 8.5 & $3.4 \pm 0.37$ & $1.2 \pm 0.1$ & $0.54 \pm 0.059$ & $-0.03 \pm 0.002$ & 1.7 & 0.7 \\
\hline \multirow[t]{3}{*}{5} & 5.5 & $1.8 \pm 0.05$ & $0.11 \pm 0.01$ & $0.17 \pm 0.005$ & $-0.30 \pm 0.028$ & na & na \\
\hline & 8.5 & $2.44 \pm 0.10$ & $0.52 \pm 0.39$ & $0.34 \pm 0.014$ & $-0.19 \pm 0.141$ & na & na \\
\hline & 11.5 & $2.45 \pm 0.16$ & $0.11 \pm 0.01$ & $0.35 \pm 0.023$ & $-0.30 \pm 0.028$ & na & na \\
\hline \multirow[t]{3}{*}{$6 a$} & 3.5 & $3.7 \pm 0.09$ & 2.5 & $0.16 \pm 0.003$ & 0.00 & na & na \\
\hline & 6.5 & $5.1 \pm 0.75$ & 2.4 & $0.35 \pm 0.051$ & -0.01 & 0.75 & 1.10 \\
\hline & 9.5 & $2.8 \pm 0.3$ & 2.5 & $0.04 \pm 0.004$ & 0.00 & na & na \\
\hline \multirow[t]{3}{*}{$6 \mathrm{~b}\left(+\mathrm{NH}_{4}\right)$} & 3.5 & $2.6 \pm 0.15$ & 2.5 & $0.01 \pm 0.001$ & 0.00 & 11.18 & 1.33 \\
\hline & 6.5 & $3.8 \pm 0.86$ & 2.5 & $0.17 \pm 0.039$ & 0.00 & 0.87 & 1.00 \\
\hline & 9.5 & $4.8 \pm 0.67$ & 2.7 & $0.31 \pm 0.043$ & 0.03 & 1.00 & 0.39 \\
\hline
\end{tabular}


$\mathrm{n}=82$ ). This value equates well with the Redfield ratio (C:N of 6.625:1)-based value of 0.8, assuming a carbon to chl a ratio of 60 .

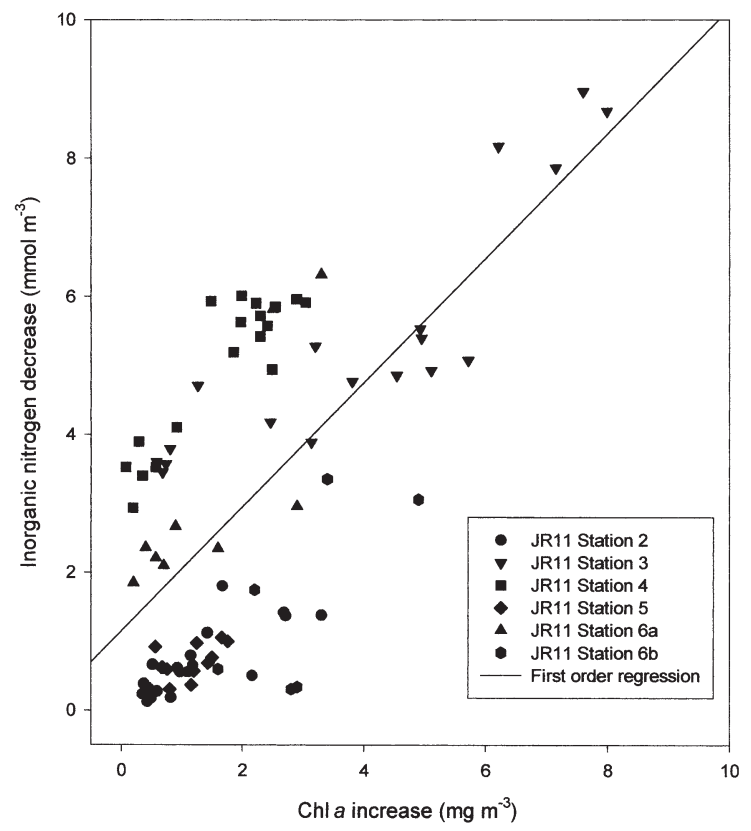

Fig. 3. Relationship between decrease in inorganic nitrogen (nitrate + ammonium) and simultaneous increase in chlorophyll $a$ on Cruise JR11. Data from elevated temperature incubations are included. Stns 6a and 6b represent control and ammonium addition $\left(1 \mathrm{mmol} \mathrm{m} \mathrm{m}^{-3}\right)$ incubations respectively; line represents first-order linear regression through all data (slope $=0.9, \mathrm{r}^{2}=0,45, \mathrm{n}=82, \mathrm{p}<0,001$ )
We calculated both specific and absolute nutrientdepletion rates for Stns 2 to 6 (Table 3). Absolute depletion rates indicate the changes in nutrient chemistry occurring in each incubation bottle with time. However, it is biomass-specific nutrient depletion which is most valuable in assessing the effect of temperature elevation on nutrient transport rates. Specific rates of silicate depletion tended to be inversely related to temperature elevation, with highest rates occurring at in situ temperatures (Table 3). No clear dependence of phosphate depletion rate on temperature was evident, with both negative and positive effects apparent across the 5 stations considered. The relationship between temperature elevation and specific nitrate depletion was also highly variable between stations, with low depletion rates associated with stations of high (>1 mmol m $\mathrm{m}^{-3}$ ) in situ ammonium concentration. Indeed, ammonium addition resulted in reduced specific nitrate uptake rate at Stn 6 with a $6^{\circ} \mathrm{C}$ temperature elevation. Specific ammoniumdepletion rates tended to be highest where in situ ammonium concentrations were also high, with ammonium addition resulting in an increase in net ammonium uptake at Stn 6. Again, no clear relationship with temperature elevation was apparent at this station. In dark incubations (data not shown), ammonium concentrations generally showed a net increase over $72 \mathrm{~h}$; however, it is worth noting that ammonium production was inversely related to ammonium concentration in these incubations. Rates of specific nutrient depletion are unavailable for Stn 1 on Cruise JR11

Table 3. Mean $\pm \mathrm{SE}(\mathrm{n}=6)$ specific $\left(\mu \mathrm{mol} \mathrm{chl} \mathrm{a} \mathrm{h}^{-1}\right)$ and absolute $\left(\mathrm{nmol} \mathrm{h} \mathrm{h}^{-1}\right)$ nutrient-depletion rates and $f$ ratio as a function of temperature elevation and station on Cruise JR11. na = not available

\begin{tabular}{|c|c|c|c|c|c|c|c|c|c|c|}
\hline \multirow[t]{2}{*}{ Stn } & \multirow{2}{*}{ Temp. $\left({ }^{\circ} \mathrm{C}\right)$} & \multicolumn{2}{|c|}{ Silicate } & \multicolumn{2}{|c|}{ Phosphate } & \multicolumn{2}{|c|}{ Nitrate } & \multicolumn{2}{|c|}{ Ammonium } & \multirow{2}{*}{$\begin{array}{l}f \text { ratic } \\
\text { (light }\end{array}$} \\
\hline & & Specific & Absolute & Specific & Absolute & Specific & Absolute & Specific & Absolute & \\
\hline \multirow[t]{3}{*}{2} & 2 & $12.6 \pm 3.7$ & $6.3 \pm 2.0$ & $14 \pm 1$ & $0.6 \pm 0.5$ & $-3.7 \pm 2.6$ & $-1.7 \pm 1.3$ & $4.0 \pm 0.9$ & $1.9 \pm 0.4$ & 0.14 \\
\hline & 5 & $7.1 \pm 2.0$ & $5.9 \pm 1.6$ & $2.0 \pm 0.3$ & $1.7 \pm 0.3$ & $-0.2 \pm 0.7$ & $-0.2 \pm 0.5$ & $5.1 \pm 0.6$ & $4.3 \pm 0.6$ & 0.08 \\
\hline & 8 & $5.8 \pm 1.2$ & $8.6 \pm 1.0$ & $1.6 \pm 0.0$ & $2.6 \pm 0.2$ & $2.8 \pm 0.8$ & $4.0 \pm 0.7$ & $4.7 \pm 0.7$ & $7.6 \pm 1.0$ & 0.35 \\
\hline \multirow[t]{3}{*}{3} & 3 & $18.3 \pm 0.8$ & $46.3 \pm 2.6$ & $0.7 \pm 0.1$ & $1.7 \pm 0.2$ & $13.8 \pm 0.4$ & $35.1 \pm 2.6$ & $0.1 \pm 0.3$ & $0.2 \pm 0.8$ & 0.98 \\
\hline & 6 & $11.1 \pm 0.5$ & $51.4 \pm 4.3$ & $0.4 \pm 0.1$ & $1.7 \pm 0.5$ & $10.0 \pm 0.6$ & $47.3 \pm 6.6$ & $0.7 \pm 0.1$ & $3.1 \pm 0.3$ & 0.93 \\
\hline & 9 & $10.1 \pm 0.2$ & $55.3 \pm 4.1$ & $0.4 \pm 0.1$ & $2.3 \pm 0.6$ & $9.9 \pm 0.5$ & $54.9 \pm 6.6$ & $0.5 \pm 0.1$ & $2.7 \pm 0.3$ & 0.95 \\
\hline \multirow[t]{3}{*}{4} & 2.5 & $18.5 \pm 1.2$ & $18.9 \pm 0.7$ & $2.5 \pm 0.1$ & $2.6 \pm 0.1$ & $25.3 \pm 1.5$ & $25.9 \pm 1.1$ & $4.7 \pm 0.3$ & $4.8 \pm 0.3$ & 0.84 \\
\hline & 5.5 & $15.3 \pm 0.4$ & $35.6 \pm 0.8$ & $1.6 \pm 0.1$ & $3.7 \pm 0.2$ & $19.5 \pm 0.7$ & $45.3 \pm 0.7$ & $1.9 \pm 0.1$ & $4.5 \pm 0.2$ & 0.91 \\
\hline & 8.5 & $14.1 \pm 0.9$ & $28.9 \pm 2.0$ & $2.0 \pm 0.2$ & $4.0 \pm 0.3$ & $21.2 \pm 1.2$ & $43.6 \pm 2.4$ & $2.2 \pm 0.5$ & $4.3 \pm 1.0$ & 0.91 \\
\hline \multirow[t]{3}{*}{5} & 5.5 & na & na & $17.9 \pm 5.4$ & $19.9 \pm 6.0$ & $8.7 \pm 4.9$ & $9.7 \pm 5.5$ & $0.5 \pm 11.4$ & $0.6 \pm 12.7$ & 0.79 \\
\hline & 8.5 & na & na & $14.1 \pm 4.0$ & $21.4 \pm 6.0$ & $2.8 \pm 1.3$ & $4.2 \pm 2.0$ & $-4.1 \pm 13.0$ & $-6.3 \pm 19.7$ & 0.53 \\
\hline & 11.5 & na & na & $14.2 \pm 3.8$ & $21.6 \pm 5.7$ & $3.1 \pm 1.6$ & $4.7 \pm 2.4$ & $7.8 \pm 4.3$ & $11.8 \pm 6.6$ & 0.71 \\
\hline \multirow[t]{3}{*}{$6 a$} & 3.5 & $-1.7 \pm 1.4$ & $-3.8 \pm 3.1$ & $0.8 \pm 0.0$ & $1.9 \pm 0.1$ & $9.7 \pm 0.8$ & $23.0 \pm 2.0$ & $-0.6 \pm 0.4$ & $-1.34 \pm 0.9$ & 1.00 \\
\hline & 6.5 & $8.9 \pm 6.5$ & $24.9 \pm 16.2$ & $1.8 \pm 0.2$ & $5.7 \pm 0.2$ & $10.2 \pm 2.0$ & $32.4 \pm 4.6$ & $0.2 \pm 0.4$ & $0.6 \pm 1.1$ & 0.99 \\
\hline & 9.5 & $-6.1 \pm 7.5$ & $-11.9 \pm 14.1$ & $4.4 \pm 1.3$ & $7.4 \pm 1.4$ & $28.3 \pm 0.8$ & $47.6 \pm 2.1$ & $-1.7 \pm 2.5$ & $-3.5 \pm 5.4$ & 0.99 \\
\hline \multirow[t]{3}{*}{$6 b$} & 3.5 & $10.5 \pm 0.8$ & $17.1 \pm 1.7$ & $1.4 \pm 0.0$ & $3.8 \pm 0.2$ & $10.0 \pm 0.3$ & $20.7 \pm 0.5$ & $3.4 \pm 0.6$ & $6.7 \pm 0.9$ & 0.75 \\
\hline & 6.5 & $4.2 \pm 1.0$ & $8.7 \pm 1.3$ & $1.8 \pm 0.5$ & $6.0 \pm 0.3$ & $8.1 \pm 2.8$ & $17.8 \pm 5.4$ & $2.0 \pm 1.4$ & $4.6 \pm 3.8$ & 0.84 \\
\hline & 9.5 & $5.4 \pm 0.8$ & $15.5 \pm 0.2$ & $1.8 \pm 0.2$ & $8.4 \pm 0.4$ & $13.9 \pm 1.8$ & $36.9 \pm 3.5$ & $2.3 \pm 0.6$ & $6.0 \pm 1.2$ & 0.86 \\
\hline
\end{tabular}


due to incorrect storage of these samples prior to chemical analysis.

Little or no net depletion of the measured nutrients was observed in dark controls over the $72 \mathrm{~h}$ incubation period, indicating that heterotrophic nutrient depletion was relatively insignificant at the 5 stations examined. The lack of significant heterotrophic inorganic nitrogen utilization at Stns 2 to 6 was also indicated by the consistent, positive relationship between $\mathrm{chl} a$ increase and inorganic nitrogen decrease (Fig. 3). However, variations in this relationship within and between stations may represent some degree of heterotrophic utilization.

Ratios of silicic acid (Si) depletion to chl a increase ( $\mathrm{Si}: \mathrm{chl}$ a) were examined wherever possible (Table 2), as high ratios can reflect the degree of nutrient stress in the diatom population of each sample (Hutchins \& Bruland 1998). High ratios occur when phytoplanktonic growth rates are lowered by nutrient stress, but silicate uptake rates remain constant. These ratios are not available for Stns 1 and 5 on Cruise JR11 because of lack of $\mathrm{Si}$ analysis at these stations. Similarly, such ratios are not available for incubations where no net silicate depletion was observed (e.g. Stn 6a). The highest Si:chl a ratios occurred at ambient temperatures, the ratio decreasing to around 1 with elevated temperature at all stations.

Low $f$ ratios, as calculated from the proportion of nitrate depletion constituting total nitrate and ammonium depletion, were associated with stations with highest in situ ammonium concentrations (Table 3). The $f$ ratio showed a highly significant negative correlation with in situ ammonium concentration (SRC, p < 0.001). This relationship was particularly conspicuous in the ammonium addition experiment (Stn 6), where the $f$ ratio showed clear variations between the 2 treatments. In the control incubations, uptake was nitrate dominated ( $f$ ratio close to 1 ) at all 3 incubation temperatures. However, in incubations with elevated ammonium (plus $1 \mathrm{mmol} \mathrm{m}^{-3}$ ), $f$ ratios were lower and were positively related to temperature increase.

A typical time course of nitrate and ammonium concentration is presented for one of the stations in Fig. 4. This shows the commonly observed pattern of inorganic nitrogen use during the study. During the first $24 \mathrm{~h}$ ammonium was rapidly reduced; after this time, ammonium depletion slowed considerably, with concentrations staying relatively constant for the rest of the incubation. Nitrate depletion, on the other hand, showed a more consistent rate throughout the incubation, the depletion rate staying constant for all but the last 12 to $24 \mathrm{~h}$, when concentrations tended to stabilize.

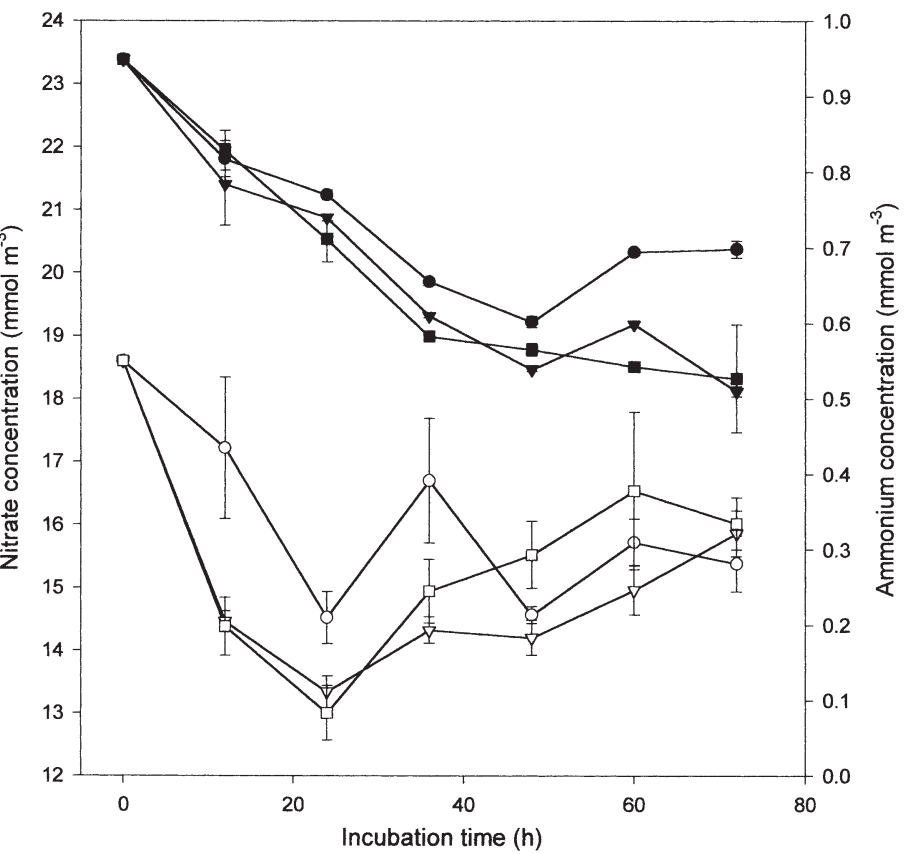

Fig. 4. Change in nitrate (black symbols) and ammonium (open symbols) concentrations with time and incubation temperature for Stn 4 . $(\bullet, \circ)$ ambient temperature, $(\boldsymbol{\Lambda}, \Delta)$ ambient plus $3^{\circ} \mathrm{C}$ elevated temperature data, $(\mathbf{\square}, \square)$ ambient plus $6^{\circ} \mathrm{C}$ elevated temperature data. Error bars $=\operatorname{SE}(n=6)$

\section{${ }^{15} \mathrm{~N}$ utilization}

Specific nitrate uptake, measured as ${ }^{15} \mathrm{~N}$-nitrate incorporation, showed a positive relationship with temperature elevation in all $3{ }^{15} \mathrm{~N}$ experiments from Cruise JR11 and in 5 out of $6{ }^{15} \mathrm{~N}$-nitrate experiments from Cruise JR38 (Fig. 5). A highly significant increase (ANOVA, Tukey $p<0.01$ ) in specific nitrate uptake rate was seen with a temperature elevation of $6^{\circ} \mathrm{C}$ at Stn $\mathrm{B}$, and with both a 3 and $6^{\circ} \mathrm{C}$ temperature elevation at Stn E. However, a temperature elevation of $6^{\circ} \mathrm{C}$ at Stn A resulted in a significant decrease (ANOVA, Tukey $\mathrm{p}<0.05$ ) in specific nitrate uptake rate. Specific nitrate uptake rates were similar across the 2 cruises, with highest rates occurring on Cruise JR38 at Stn A.

In the 3 experiments from Cruise JR11, the biomassspecific nitrate uptake rate by the whole phytoplankton assemblage was generally greater than that of the $<20 \mu \mathrm{m}$ fraction, although nitrate uptake by the $<20 \mu \mathrm{m}$ fraction followed a trend with temperature elevation similar to that seen for the whole assemblage. Dark nitrate uptake was low or negligible where measured, aside from a peak in uptake rate at Stn 9 at the highest temperature elevation (ambient plus $6^{\circ} \mathrm{C}$ ). Specific nitrate uptake rates for the 3 nitrate incorporation experiments on Cruise JR11 each represent an analysis of bulked triplicate samples due to problems of detection using individual samples. 

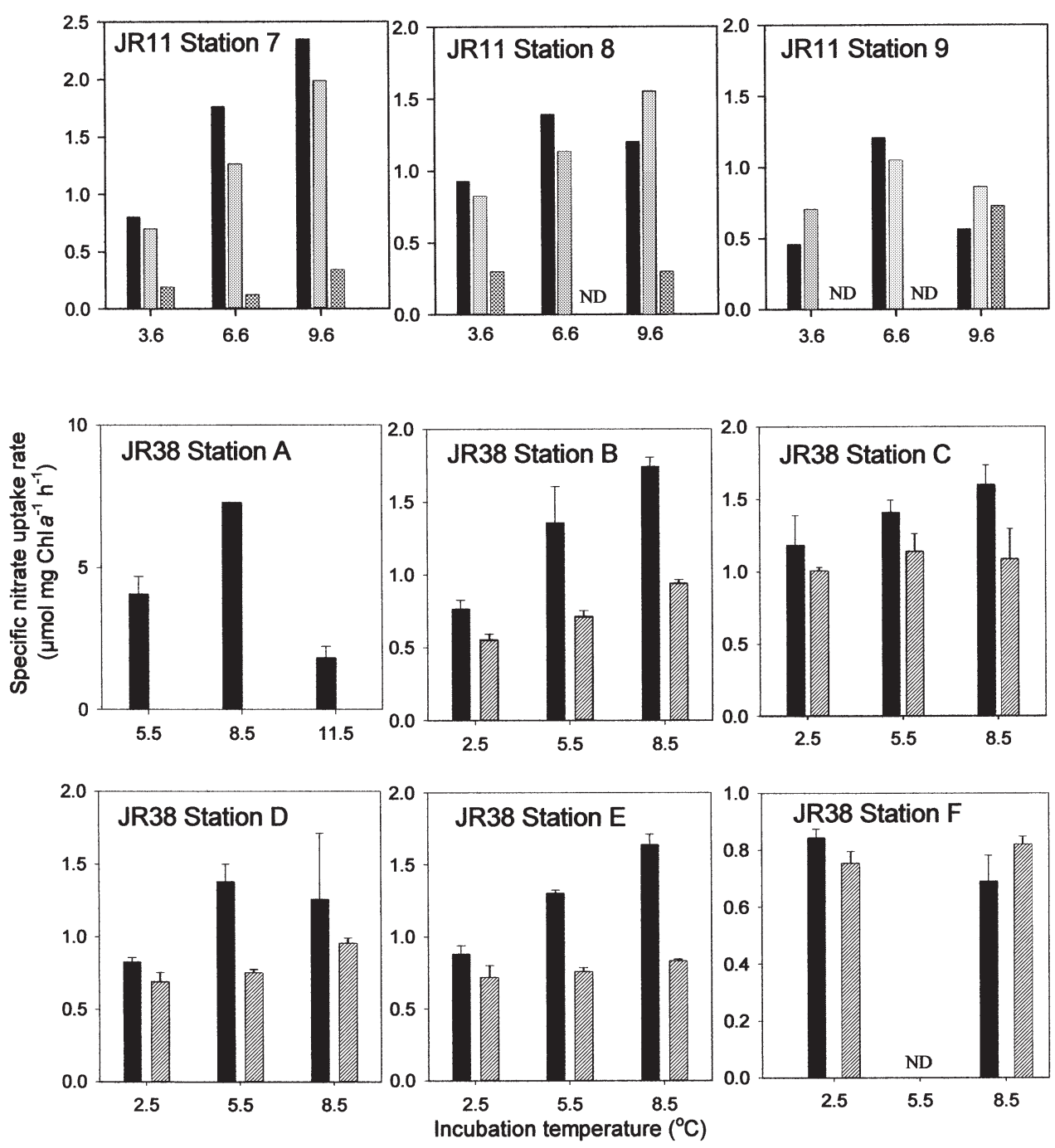

Illuminated unfiltered

Illuminated filtered $(<20 \mu \mathrm{m})$

Dark unfiltered

Illuminated unfiltered, $1 \mu \mathrm{M}$ ammonium addition

Fig. 5. Effect of temperature elevation and ammonium addition $\left(1 \mathrm{mmol} \mathrm{m}{ }^{-3}\right)$ on specific ${ }^{15} \mathrm{~N}$-nitrate at 9 stations on Cruises JR11 and JR38. Error bars represent SE $(n=3)$. ND: insufficent biomass for detection of ${ }^{15} \mathrm{~N}$-nitrate

The lowest rates of ${ }^{15} \mathrm{~N}$-nitrate uptake from both cruises tended to coincide with the highest ambient ammonium concentrations. Similarly, the $1 \mathrm{mmol} \mathrm{m}^{-3}$ supplementation of ammonium in experiments from JR38 consistently reduced specific nitrate uptake rate at both ambient and elevated temperatures. Despite the reduction in specific nitrate uptake rate caused by ammonium addition, a significant increase (ANOVA, Tukey $\mathrm{p}<0.05$ ) in uptake rate was still observed with elevated temperatures at Stns B and D. Aside from Stn $F$, the negative effect of ammonium addition on biomass-specific nitrate uptake rate was significant $($ ANOVA, $\mathrm{p}<0.05)$ at all stations where ammonium additions were made. However, the addition of ammonium appeared to have the greatest effect at elevated temperatures. No data were available for the first temperature elevation (ambient plus $3^{\circ} \mathrm{C}$ ) at Stn $\mathrm{F}$ on Cruise JR38 due to failure of the thermocirculator.

Iron addition experiments were made at Stns $\mathrm{A}$ and D. A significant (ANOVA, $p<0.05$ ) positive effect of iron addition on biomass specific nitrate uptake rate was observed at Stn A, although this effect was apparent at elevated rather than ambient temperature (Table 4). Iron addition to Stn A incubations at a temperature elevation of ambient plus $3^{\circ} \mathrm{C}$ resulted in more than a 3 -fold increase in specific nitrate uptake 
Table 4. Effect of iron addition $\left(10 \mu \mathrm{mol} \mathrm{m}{ }^{-3}\right)$ on ${ }^{15} \mathrm{~N}$-nitrate

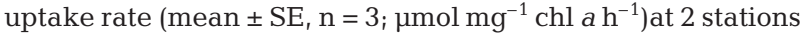
on Cruise JR38. nd = insufficient biomass for detection of

${ }^{15} \mathrm{~N}$-nitrate

\begin{tabular}{|lccc|}
\hline Stn & $\begin{array}{c}\text { Incubation } \\
\text { temperature }\left({ }^{\circ} \mathrm{C}\right)\end{array}$ & $\begin{array}{c}\text { Ambient } \\
\text { iron }\end{array}$ & $\begin{array}{c}10 \mu \mathrm{mol} \mathrm{m}^{-3} \\
\text { iron addition }\end{array}$ \\
\hline $\mathrm{A}$ & 5.5 & $4.1 \pm 0.61$ & $2.3 \pm 1.74$ \\
& 8.5 & 7.3 & 23.9 \\
$\mathrm{D}$ & 11.5 & $1.8 \pm 0.41$ & $\mathrm{nd}$ \\
& 3.5 & $1.07 \pm 0.02$ & $1.31 \pm 0.18$ \\
& 9.5 & $1.07 \pm 0.16$ & 1.76 \\
\hline
\end{tabular}

rate over that seen in ambient iron controls. No significant effect (ANOVA, $p=0.06$ ) of iron addition on specific nitrate uptake was seen at Stn $\mathrm{D}$; however, the low number of usable replicates in this experiment made any statistical analysis problematic. Where no specific nitrate uptake rate is given, levels of ${ }^{15} \mathrm{~N}$-nitrate were below detectable levels due to insufficient biomass on the sample collection filters.

Concentrations of ambient iron were below detection levels $\left(<0.25 \mu \mathrm{mol} \mathrm{m}^{-3}\right)$ at both Stns A and D, with no evidence for any iron contamination during Go-Flo bottle sampling. Subsequent analysis of iron concentrations in water samples incubated under standard conditions for $48 \mathrm{~h}$ showed a slight increase in iron concentration to between 0.6 and $1.8 \mu \mathrm{mol} \mathrm{m}{ }^{-3}$, indicating some small introduction of Fe during experimentation, possibly by leaching from incubation bottles.

\section{DISCUSSION}

\section{Physicochemical environment and the phytoplankton community}

Water temperatures $\left(2\right.$ to $\left.5.5^{\circ} \mathrm{C}\right)$ encountered during the 2 cruises are consistent with those previously recorded for this part of the Southern Ocean during summer (e.g. Whitehouse et al. 1996). The consistently high nitrate and phosphate concentrations, together with generally low chl a levels are also commonly observed features of the Southern Ocean (Dugdale \& Wilkerson 1991). The lack of any significant relationship between in situ temperature and chl a or nutrient concentrations is not surprising, given the large heterogeneity of this region and the consequently wideranging nutrient histories of the experimental stations. Instead, it is more valuable to examine temperaturechange effects where all other factors are equal, as attempted in this study.

The large representation of small $(<20 \mu \mathrm{m})$ phytoplankton identified in the algal assemblage at Stns 7, 8 and 9 is not uncommon for open-sea areas of the
Southern Ocean (Hewes et al. 1985). Areas dominated by larger $(>20 \mu \mathrm{m})$ phytoplankton are often encountered at ice-edge and inshore stations (Kang \& Lee 1995), although such phytoplankton may also be prevalent in open waters (Whitehouse et al. 1996).

\section{Growth rates}

Growth rates of the phytoplankton incubated at ambient temperatures were in the range measured for Southern Ocean algae in previous studies (e.g. Fiala \& Oriol 1990, Cota et al. 1992). Similarly, the clear importance of temperature to phytoplankton growth in this region concurs with the findings of Bracher et al. (1999). Our study indicates that the dominant phytoplankton in the area around South Georgia are not adapted for maximal growth at the low ambient temperatures encountered, and that either directly or indirectly these low temperatures may limit potential primary production and nutrient drawdown. This agrees with the findings of several previous studies of oceanic phytoplankton in the Southern Ocean (e.g. Neori and Holm-Hansen 1982, Jacques 1983, Tilzer et al. 1986). Given the apparent regulation of phytoplankton growth by low temperature, one may wonder why psychrophillic algal species are not more dominant in these waters. However, it seems that the costs of adaptation to specialized low-temperature growth commonly balance the benefits in this environment. Indeed, as stated by Russell (1990) 'it is not necessary for a microbe to function at optimal rates as long as it can compete effectively in its particular environment'.

Although we recognize that the degree of uncoupling between $\mathrm{chl}$ a increase and biomass production may increase at elevated temperature, our study indicates that, even with this taken into account, temperature elevation resulted in greatly increased algal growth rates. The observed increases in chl $a$, particularly at elevated temperatures, are likely to be conservative estimates, as no account was taken of possible losses due to grazing within experiments. However, the lack of any significant change in chl a concentration in blacked-out bottles indicates that grazing losses, if any, were relatively small over the duration of these experiments.

The positive relationship between inorganic nitrogen uptake and chl a production evident at all stations indicates that the increases in chl a observed at elevated temperature did indeed represent an increase in growth rate. However, the variation in the strength of this relationship between stations indicates that a certain degree of uncoupling between chl $a$ increase and biomass accumulation did occur, particularly at Stns 5, $6 \mathrm{a}$ and $6 \mathrm{~b}$. 
The Si depletion to chl a increase ratios (Si:chl a) of around 1 generally seen at elevated temperatures, indicated rapid diatom growth under nutrient-replete conditions. However, the higher Si:chl a ratios observed at ambient temperature (particularly at Stns 3 and 4) indicated a more heavily silicified diatom biomass growing under nutrient stress. Such heavy silicification has previously been attributed to iron limitation, where the slowing of growth rate by iron limitation is combined with a constant silicate uptake rate and so excess silicate loading per cell (Hutchins \& Bruland 1998). Measurements of in situ iron concentrations in this area on the second cruise (JR38) add some credence to this theory, iron concentrations being undetectable $\left(<0.25 \mu \mathrm{mol} \mathrm{m} \mathrm{m}^{-3}\right)$ at the 2 stations where it was measured.

If iron limitation was indeed responsible for high silicification at ambient temperatures in this study, then an alleviation of iron limitation by temperature elevation seems evident. However, an increased Si:chl a ratio at low temperature may also result from nitrogen limitation, differential growth response of diatoms and nondiatoms to temperature change, or the fact that the enzymes responsible for synthesis of most organic components of diatom cell walls have a higher $Q_{10}$ than $\mathrm{Si}$ crystallization (where $Q_{10}$ represents the ratio of the rate constants for a reaction at 2 temperatures $10^{\circ} \mathrm{C}$ apart).

\section{Specific nutrient depletion}

The inverse relationship generally seen between specific silicate depletion and temperature supports the idea of heavier silicification of diatoms at ambient temperature due to nutrient stress, as identified through Si:chl a ratios. However, assuming that elevated temperature increases the availability of iron, the increase in dominance of diatoms which is often seen with iron addition (e.g. Coale et al. 1996) may counteract this trend given sufficient time ( $>5 \mathrm{~d}$ ).

The variability in response of specific nitrate depletion to temperature elevation may be a result of the interaction between in situ ammonium concentration and nitrate uptake. Certainly, the previously reported trends of low temperature limitation of nitrate transport (Sakamoto \& Bryant 1998) and affinity (Reay et al. 1999) involved laboratory studies where nitrate was the sole $\mathrm{N}$ source and where any significant ammonium effect was unlikely.

Several studies have identified a negative relationship between nitrate uptake and ammonium concentrations in the range encountered in this study (e.g. Dortch 1990, Flynn et al. 1997, Lomas \& Glibert 1999a, Page et al. 1999), with studies in the Southern Ocean also supporting this relationship (Glibert et al. 1982,
Owens et al. 1991, Mengesha et al. 1998). A recent model proposed the co-limitation of nitrate and phytoplankton growth in HNLC areas by iron, light and ammonium (Armstrong 1999). Certainly, the coincidence of highest nitrate depletion with stations of lowest ambient ammonium concentration agrees with the hypothesis of inhibition by, or preference for, ammonium where ammonium concentrations are high (>1 $\mathrm{mmol} \mathrm{m}^{-3}$ ). Similarly, the trend of low depletion/ net increase of nitrate at stations with high in situ ammonium concentrations agrees well with such an ammonium effect.

The positive relationship generally observed between ambient ammonium concentration and specific ammonium uptake also reflects the often observed preference for ammonium over nitrate by phytoplankton when ammonium concentrations are high (Olson 1980, Dortch 1990). The absence of any clear temperature dependence of specific ammonium uptake agrees with our previous study, which indicated little temperaturedependence of affinity for ammonium in a range of algae and bacteria (Reay et al. 1999). However, Priscu et al. (1989) identified a temperature dependence of both nitrate and ammonium uptake in sea-ice microalgae.

The lack of significant nutrient depletion via heterotrophic uptake agrees with other studies in this area which have reported bacterial impact in surface waters to be relatively small compared to that of the phytoplankton (e.g. Bird \& Karl 1999). However, under certain conditions heterotrophic nutrient depletion can be very significant, particularly in coastal/ice-edge areas or in post-bloom conditions (e.g. Robinson et al. 1999, Vanucci \& Bruni 1999).

The negative correlation between ammonium concentration and the $f$ ratio seen in this study can be attributed to both the inhibition of nitrate uptake by high ammonium concentrations and to the increase in ammonium depletion rate associated with high ammonium concentrations. Reported $f$ ratios for the Southern Ocean vary widely, and reflect both the heterogeneous nature of this area and the seasonality of nitrogen preference. Ammonium concentrations are generally low early in the spring and nitrogen uptake tends to be dominated by nitrate use, with consequently high $f$ ratios. However, despite the fact that nitrate concentrations are rarely depleted to what would be considered limiting concentrations in temperate oceanic areas, ammonium utilization becomes increasingly important during the course of the season, with a shift from predominantly new to regenerated production (Mengesha et al. 1998). Increasing evidence suggests that the reduced forms of $N$, such as ammonium and urea, may be less temperature-dependent than nitrate, so further increasing their importance as $\mathrm{N}$ sources at low temperatures. Reay et al. 
(1999) showed specific affinity for ammonium in a range of microalgae and bacteria to be much less dependent on temperature than affinity for nitrate. Likewise, Sakamoto \& Bryant (1998) showed that while cells of the unicellular cyanobacterium Synechococcus sp. became chlorotic and grew arithmetically at low temperature when grown solely on nitrate, they grew exponentially, with no symptoms of chlorosis, with urea as their nitrogen source.

The representative time course of nitrate and ammonium depletion highlights the large changes in nitrogen utilization over the course of the $72 \mathrm{~h}$ incubations. Rather than the microalgal community simultaneously using both nitrate and ammonium throughout the incubation, it appears that ammonium is quickly depleted to a point where little further net depletion can occur. Nitrate, on the other hand, shows a more uniform pattern of depletion with time, becoming increasingly favoured as the ammonium concentration falls. It appears that the microalgal community is able to rapidly switch between nitrogen sources depending on their relative concentrations, an important ability where inorganic nitrogen supply may be episodic and confined to small patches.

\section{${ }^{15} \mathbf{N}$ uptake}

The positive relationship between temperature and ${ }^{15} \mathrm{~N}$-nitrate incorporation, seen at 8 of the 9 stations where ${ }^{15} \mathrm{~N}$-nitrate uptake was measured, is in accord with previous studies of nitrate uptake by marine phytoplankton (Olson 1980, Le Bouteiller 1986, Priscu et al. 1989, Glibert \& Garside 1992, Dauchez et al. 1996). This trend is also consistent with studies of the temperature-dependence of nitrate assimilation and affinity (Gao et al. 1993, Reay et al. 1999) and with studies of nitrate transport in the freshwater cyanobacterium Synechococcus sp. (Sakamoto \& Bryant 1997, 1998, 1999). However, the opposite trend has been reported for cool-water diatoms in Chesapeake and Delaware Bays (Lomas \& Glibert 1999b). In our study, the clear dependence of nitrate uptake on temperature is further demonstrated by the trend of increasing specific nitrate uptake even where ammonium concentrations are elevated. Within the range of ammonium concentrations encountered in this region, temperature plays a part in the control of nitrate use.

The trend of greater specific nitrate uptake rate in the whole phytoplanktonic assemblage compared to that in the $<20 \mu \mathrm{m}$ fraction is consistent with a preference of small phytoplankton for ammonium, compared to large phytoplankton which tend to rely more on nitrate as an N source (Dortch 1990, Owens et al. 1991). We have suggested previously (Reay et al. 1999) that a reliance of phytoplankton on passive $\mathrm{NH}_{3}$ uptake may favour nano- and picoplankton over larger plankton. Similarly, passive uptake of urea could favour phytoplankton with a large surface area to volume ratio.

The negative effect of high ammonium concentrations on nitrate utilization is underscored by the ${ }^{15} \mathrm{~N}$ nitrate incorporation experiments. It is clear that, irrespective of temperature, ammonium concentrations may have a significant effect on specific nitrate depletion in the area studied. However, the absolute values of ammonium at which nitrate use becomes limited are highly contentious, and several workers have reported no inhibition even at concentrations $>1 \mathrm{mmol} \mathrm{m}^{-3}$ (Dortch 1990). It is likely that the effect of ammonium concentration on nitrate utilization is modified by a variety of factors (Armstrong 1999), such as community composition and previous nitrogenous nutrition of the microalgal assemblage. The importance of ammonium inhibition of nitrate uptake to the maintenance of HNLC conditions in the Subarctic northeastern Pacific has already been suggested (Wheeler \& Kokkinakis 1990, Varela and Harrison 1999). Our study now provides further evidence that this factor may also be important in the maintenance of the Southern Ocean HNLC region. The additive effect of low temperature and elevated ammonium in limiting nitrate uptake again shows the importance of considering more than just one factor when attempting to parameterize nitrate use in this area.

Some divergence in the rate and trend of nitrate uptake measured with ${ }^{15} \mathrm{~N}$-nitrate incorporation versus that measured in the simple nutrient-depletion experiments was evident during this study. This divergence is likely to have arisen as a result of the greater incubation time of the simple depletion experiments, with a consequently increased likelihood of ammonium regeneration and more complex nitrate uptake dynamics.

The very low in situ iron concentrations encountered at the 2 stations where iron was measured agree with values reported previously for this region (Löscher et al. 1997). The lack of a significant increase in specific nitrate uptake rate with iron addition is slightly surprising considering these very low in situ concentrations. However, low concentrations of a nutrient do not necessarily translate to limiting concentrations, factors such as low temperature may be as important as direct iron limitation of nitrate use at in situ temperatures in the Southern Ocean. The increase in specific nitrate uptake rate seen at elevated temperature with iron addition, relative to incubations without iron addition, argues that it is the low in situ temperature that limits nitrate use in this instance. Some interaction between temperature and iron limitation seems evident in such a case, with low temperature limitation of iron uptake being a likely component. 


\section{Ecological implications for the Southern Ocean HNLC region}

The importance of temperature to algal growth is now well established in many aquatic environments (Eppley 1972, Raven \& Geider 1988). Our results suggest that under optimal conditions, increased environmental temperature in the Southern Ocean of only 1 to $2{ }^{\circ} \mathrm{C}$ could result in significantly higher rates of nitrate utilization and microalgal growth. Obviously, the effect of oceanic warming on net primary production is, in practice, a highly complex one, with factors such as grazing, nutrient recycling and water-column stability all being sensitive to temperature change. However, this study provides valuable information both on the potential importance of temperature in the maintenance of the Southern Ocean as an HNLC region and the effects that temperature change may have.

When the inhibitory effect of high ammonium concentration $\left(\approx 1 \mathrm{mmol} \mathrm{m}^{-3}\right)$ on nitrate use is coupled with the trend of increased ammonium-depletion rates with increased ammonium concentrations, the significance of ammonium to Southern Ocean microalgae becomes apparent. Ammonium is typically found at much lower concentrations than nitrate, and is supplied by recycling as the result of microbial activity and zooplankton grazing in the euphotic zone (Priddle et al. 1997) and remineralization by land-based endotherms (Whitehouse et al. 1999). However, under Southern Ocean conditions, phytoplankton often cannot utilize fully the larger pool of nitrate present in the water. This study indicates that the combined effects of reduced affinity for nitrate at low temperature and preferential assimilation of ammonium where ammonium concentrations exceed $\approx 1 \mathrm{mmol} \mathrm{m} \mathrm{m}^{-3}$ may contribute to this incomplete utilization of nitrate. Phytoplankton production is therefore potentially regulated in part by the rate of remineralisation and ammonium production (Priddle et al. 1997).

Although it seems likely that iron is often present in the Southern Ocean at limiting concentrations, our study of the effects of temperature and ammonium on nitrate uptake and phytoplankton growth suggest that enhanced iron concentration alone may not always enable phytoplankton to utilize the nitrate pool fully. This may be due to the lower affinity for nitrate at low temperature (Reay et al. 1999) and the additional energetic cost of nitrate uptake and assimilation compared to that for ammonium. Furthermore, under low temperature conditions, requirements for iron in both the electron transport system and in nitrate- and nitritereductases (Dugdale \& Wilkerson 1991, Price et al. 1991) could be elevated if the algae were to respond by increasing the number of enzyme-active sites (Maldonado \& Price 1996). A situation could therefore be conceived whereby nitrate in the Southern Ocean is not fully utilized due to insufficient iron availability, an insufficiency which itself is exacerbated by low temperature. Obviously the temperature-dependence of iron utilization needs to be established for such an indirect effect of low temperature on nitrate utilization and algal growth. However, as indicated earlier, the active nature of iron uptake so far identified for microorganisms (Lesuisse et al. 1991) certainly presages temperature dependence.

There have been many suggestions to explain HNLC conditions in both the Southern Ocean and elsewhere (see Cullen 1991). Limitation of nutrient drawdown and primary production by low concentrations of trace elements, especially iron (e.g. Martin \& Fitzwater 1988), seems of obvious importance, but should not be taken as the sole and independent determinant. The heterogeneous nature of HNLC regions, coupled with interactions between limiting factors, means that colimitation of nitrate use and phytoplankton growth in the Southern Ocean is the more likely large-scale scenario, rather than direct limitation by a single factor. This study supports the idea outlined by Armstrong (1999) that the various factors cited as responsible for HNLC conditions should be viewed not as alternatives, but as part of a whole.

Acknowledgements. This work was carried out both during the tenure by David S Reay of a CASE research studentship (GT4/94/339/L) awarded to D.B.N., J.P. and J.C.E.-E. by the Natural Environment Research Council, UK, and during the tenure by C.D. of a CASE research studentship (GT04/97/ MAS/98) awarded to D.B.N. and J.P. The authors would like to thank the officers and crew of the British Antarctic Survey RV 'James Clark Ross' for their help in sample collection, and also Mr Chris Quarmby at the Institute of Terrestrial Ecology, Merlewood, Cumbria, for his assistance with ${ }^{15} \mathrm{~N}$ analyses.

\section{LITERATURE CITED}

Anderson G, Lesuisse E, Dancis A, Roman D, Labbe P, Klausner R (1992) Ferric iron reduction and iron assimilation in Saccharomyces cervisiae. J Inorg Biochem 47:249-255

Armstrong R (1999) An optimization-based model of ironlight-ammonium colimitation of nitrate uptake and phytoplankton growth. Limnol Oceanogr 44:1436-1446

Barber RT, Dugdale RC, MacIsaac JJ, Smith RL (1971) Variations in phytoplankton growth associated with the source and conditioning of upwelling water. Investig Pesq 35: 171-193

Barrie A, Prosser SJ (1996) Automated analysis of lightelement stable isotopes by isotope ration mass spectrometry. In: Boutton TW, Yamasaki SI (eds) Mass spectrometry of soils. Marcel Dekker, Inc, New York, p 1-46

Basterretxea G, Aristegui J (1999) Phytoplankton biomass and production during late austral spring (1991) and summer (1993) in the Bransfield Strait. Polar Biol 21:11-22

Behrenfeld MJ, Bale AJ, Kolber ZS, Aiken J, Falkowski PG (1996) Confirmation of iron limitation of phytoplankton 
photosynthesis in the equatorial Pacific Ocean. Nature 383:508-513

Bird D, Karl D (1999) Uncoupling of bacteria and phytoplankton during the austral spring bloom in Gerlache Strait, Antarctic Peninsula. Aquat Microb Ecol 19:13-27

Boyd P, LaRoche J, Gall M, Frew R, McKay RML (1999) Role of iron, light, and silicate in controlling algal biomass in subantarctic water SE of New Zealand. J Geophys Res 104(C6):13395-13408

Bracher A, Kroon B, Lucas M (1999) Primary production, physiological state and composition of phytoplankton in the Atlantic Sector of the Soutern Ocean. Mar Ecol Prog Ser 190:1-16

Bruland KW, Franks RP, Knauer GA, Martin JH (1979) Sampling and analytical methods for the determination of copper, cadmium, zinc, and nickel at the nanongram per liter level in sea water. Anal Chim Acta 105:233-245

Buma A, Debaar H, Nolting R, Vanbennekom A (1991) Metal enrichment experiments in the Weddel-Scotia Seaseffects of iron and manganese on various plankton communities. Limnol Oceanogr 36:1865-1878

Chisholm SW, Morel FMM (1991) What controls phytoplankton production in nutrient-rich areas of the open sea? Limnol Oceanogr 36: Preface

Coale KH, Johnson KS, Fitzwater SE, Gordon RM, Tanner S, Chavez FP, Ferioli L, Sakamoto C, Rogers P, Millero F, Steinberg $\mathrm{P}$, Nightingale $\mathrm{P}$, Cooper D, Cochlan WP, Landry MR, Constantinou J, Rollwagen G, Trasvina A, Kudela R (1996) A massive phytoplankton bloom induced by an ecosystem-scale iron fertilization experiment in the equatorial Pacific Ocean. Nature 383:495-501

Cota GF, Smith WO, Nelson DM, Muench RD, Gordon LI (1992) Nutrient and biogenic particulate distributions, primary productivity and nitrogen uptake in the WeddellScotia Sea marginal ice zone during winter. J Mar Res 50: 155-181

Cullen JJ (1991) Hypotheses to explain high-nutrient conditions in the open sea. Limnol Oceanogr 36:1578-1599

Dauchez S, Legendre L, Fortier L, Levasseur M (1996) Nitrate uptake by size-fractionated phytoplankton on the Scotian Shelf (Northwest Atlantic): spatial and temporal variability. J Plankton Res 18:577-595

DeBaar HJW (1990) On iron limitation in the Southern Ocean: experimental observations in the Weddell and Scotia Seas. Mar Ecol Prog Ser 65:105-122

DeBaar H, Dejong J, Bakker D, Loscher B, Veth C, Bathmann U, Smetacek V (1995) Importance of iron for plankton blooms and carbon-dioxide drawdown in the SouthernOcean. Nature 373:412-415

Dortch Q (1990) The interaction between ammonium and nitrate uptake in phytoplankton. Mar Ecol Prog Ser 61: 183-201

Dugdale RC, Goering JJ (1967) Uptake of new and regenerated forms of nitrogen in primary productivity. Limnol Oceanogr 12:196-206

Dugdale RC, Wilkerson FP (1991) Low specific nitrate uptake rate: a common feature of high-nutrient, low-chlorophyll marine ecosystems. Limnol Oceanogr 36:1678-1688

Eppley RW (1972) Temperature and phytoplankton growth in the sea. Fish Bull 70:1063-1085

Fiala M, Oriol L (1990) Light-temperature interactions on the growth of Antarctic diatoms. Polar Biol 10:629-636

Flynn KJ, Fasham MJR, Hipkin CR (1997) Modelling the interactions between ammonium and nitrate uptake in marine phytoplankton. Philos Trans R Soc Lond Biol Sci 352:1-22

Frost BW (1996) Phytoplankton bloom on iron rations. Nature 383:475-476
Gao Y, SmithG, Alberte R (1993) Nitrate-reductase from the marine diatom Skeletonema costatum-biochemical and immunological characterization. Plant Physiol 103: $1437-1445$

Geider RJ, MacIntyre HL, Kana TM (1997) Dynamic model of phytoplankton growth and acclimation: responses of the balanced growth rate and the chlorophyll a:carbon ratio to light, nutrient limitation and temperature. Mar Ecol Prog Ser 148:187-200

Glibert PM, Garside P (1992) Diel variability in nitrogenous nutrient uptake by phytoplankton in the Chesapeake Bay plume. J Plankton Res 14:271-288

Glibert PM, Biggs DC, McCarthy JJ (1982) Utilization of ammonium and nitrate during austral summer in the Scotia sea. Deep-Sea Res Part A Oceanogr Res Pap 29(7): $837-850$

Hart TJ (1934) On the phytoplankton of the south-west Atlantic and Bellinghausen Sea, 1929-31. Discov Rep 8: $1-268$

Herbert RA, Bhakoo M (1979) Microbial growth at low temperatures. In: Russell AD, Fuller R (eds) Cold tolerant microbes in spoilage and the environment. Academic Press, London, p 1-16

Hewes CD, Holm-Hansen O, Sakshaug E (1985). Alternate carbon pathways at lower trophic levels in the Antarctic food web. In: Siegfried WR, Condy PR, Laws RM (eds) Antarctic nutrient cycles and food webs. Springer-Verlag, Berlin, p 277-284

Hutchins DA, Bruland KW (1998) Iron-limited diatom growth and $\mathrm{Si}: \mathrm{N}$ uptake ratios in a coastal upwelling regime. Nature 393:561-564

Jacques G (1983) Some ecophysiological aspects of Antarctic phytoplankton. Polar Biol 2:27-33

Joos F, Siegenthaler U, Sarimento JL (1991) Possible effects of iron fertilization in the Southern Ocean on atmospheric $\mathrm{CO}_{2}$ concentrations. Global Biogeochem Cycles 5: $135-150$

Kang SH, Lee S (1995) Antarctic phytoplankton assemblage in the western Bransfield Strait region, February 1993: composition, biomass, and mesoscale distributions. Mar Ecol Prog Ser 129:253-267

Kirkwood DS (1996) Nutrients: practical notes on their determination in seawater. ICES, Copenhagen, Denmark

Le Bouteiller A (1986) Environmental control of nitrate and ammonium uptake by phytoplankton in the Equatorial Atlantic Ocean. Mar Ecol Prog Ser 30:167-179

Lesuisse E, Horion B, Labbe P, Hilger F (1991) The plasmamembrane ferrireductase activity of Saccharomyces cervisiae is partially controlled by cyclic-AMP. Biochem J 280:545-548

Lesuisse E, Simon-Cassteras M, Labbe P (1998) Siderophoremediated iron uptake in Saccharomyces cerevisiae: the SIT1 gene encodes a ferrioxamine $B$ permease that belongs to the major facilitator superfamily. Microbiology 144:3455-3462

Li W (1985) Photosynthetic response to temperature of marine phytoplankton along a latitudinal gradient (16-degrees-N to 74-degrees-N). Deep-Sea Res Part A Oceanogr Res Pap 32:1381-1391

Li W, Smith J, Platt T (1984) Temperature response of photosynthetic capacity and carboxylase activity in arctic marine phytoplankton. Mar Ecol Prog Ser 17:237-243

Lomas M, Glibert P (1999a) Interactions between $\mathrm{NH}_{4}{ }^{+}$and $\mathrm{NO}_{3}{ }^{-}$uptake and assimilation: comparison of diatoms and dinoflagellates at several growth temperatures. Mar Biol 133:541-551

Lomas MW, Glibert PM (1999b) Temperature regulation of 
nitrate uptake: a novel hypothesis about nitrate uptake and reduction in cool-water diatoms. Limnol Oceanogr 44: $556-572$

Löscher BM, de Barr JTM, Veth C, Dehaurs F (1997) The distribution of $\mathrm{Fe}$ in the Antarctic Circumpolar Current. Deep-Sea Res Part II Top Stud Oceanogr 44:143-187

Maldonado MT, Price NM (1996) Influence of N substrate on Fe requirements of marine centric diatoms. Mar Ecol Prog Ser 141:161-172

Martin JH, Fitzwater SE (1988) Iron deficiency limits phytoplankton growth in Antarctic waters. Nature 331:341-343

Martin JH, Gordon RM, Fitzwater SE (1990) Iron in Antarctic waters. Nature 345:156-158

Mengesha S, Dehairs F, Fiala M, Elskens M, Goeyens L (1998) Seasonal variation of phytoplankton community structure and nitrogen uptake regime in the Indian Sector of the Southern Ocean. Polar Biol 20:259-272

Minas HJ, Minas M, Packard TT (1986) Productivity in upwelling areas deduced from hydrographic and chemical fields. Limnol Oceanogr 31:1182-1206

Nedwell DB, Rutter M (1994. Influence of temperature on growth rate and competition between two psychrotolerant Antarctic bacteria: low temperature diminishes affinity for substrate uptake. Appl Environ Microbiol 60: 1984-1992

Neori A, Holm-Hansen O (1982) Effect of temperature on rates of photosynthesis in Antarctic phytoplankton. Polar Biol 1:33-38

Olson RJ (1980) Nitrate and ammonium uptake in Antarctic waters. Limnol Oceanogr 25:1064-1074

Owens NJP, Priddle J, Whitehouse MJ (1991) Variations in phytoplanktonic nitrogen assimilation around South Georgia and in the Bransfield Strait (Southern Ocean). Mar Chem 35:287-304

Page S, Hipkin C, Flynn K (1999) Interactions between nitrate and ammonium in Emiliania huxleyi. J Exp Mar Biol Ecol 236:307-319

Parsons TR, Maita Y, Lalli CM (1984) A manual of chemical and biological methods for seawater analysis. Pergamon Press, Oxford

Price NM, Andersen LF, Morel FMM (1991) Iron and nitrogen nutrition of equatorial Pacific plankton. Deep-Sea Res 38: 1361-1378

Priddle J, Smetacek V, Bathmann U (1992) Antarctic marine primary production, biogeochemical cycles and climate change. Philos Trans R Soc Lond B Biol Sci 338:289-297

Priddle J, Whitehouse MJ, Atkinson A, Brierley AS, Murphy EJ (1997) Diurnal changes in near-surface layer ammonium concentration - interplay between zooplankton and phytoplankton. J Plankton Res 19:1305-1330

Priscu JC, Palmisano AC, Priscu LR, Sullivan CW (1989) Temperature dependence of inorganic nitrogen uptake and assimilation in Antarctic sea-ice microalgae. Polar Biol 9: 443-446

Raven JA, Geider RJ (1988) Temperature and algal growth. New Phytol 110:441-461

Reay DS, Nedwell DB, Priddle J, Ellis-Evans JC (1999) Temperature dependence of inorganic nitrogen uptake: reduced affinity for nitrate at suboptimal temperatures in both algae and bacteria. Appl Environ Microbiol 65: $2577-2584$

Robinson C, Archer S, Williams P (1999) Microbial dynamics in coastal waters of East Antarctica: plankton production and respiration. Mar Ecol Prog Ser 180:23-36

Russell NJ (1990) Cold adaptation of microorganisms. Phil Trans R Soc Lond 326:595-611

Sakamoto T, Bryant DA (1997) Low temperature acclimation and nitrogen limitation in the cyanobacterium Synechococcus sp. strain PCC 7002. Plant Physiol 114: p 595

Sakamoto T, Bryant DA (1998) Growth at low temperature causes nitrogen limitation in the cyanobacterium Synechococcus sp. PCC 7002. Arch Microbiol 169:10-19

Sakamoto T, Bryant DA (1999) Nitrate transport and not photoinhibition limits growth of the freshwater cyanobacterium Synechococcus species PCC 6301 at low temperature. Plant Physiol 119:785-794

Sarmiento JL, Orr JC (1991) Three-dimensional simulations of the impact of Southern Ocean nutrient depletion on atmospheric $\mathrm{CO}_{2}$ and ocean chemistry. Limnol Oceanogr 36:1928-1950

Scharek R, VanLeeuwe M, DeBarr H (1997) Responses of Southern Ocean phytoplankton to the addition of trace metals. Deep-Sea Res Part II Top Stud Oceanogr 44: 209-227

Sedwick PN, DiTullio GR, Hutchins DA, Boyd PW, Griffiths FB Crossley AC, Trull TW, Queguiner B (1999) Limitation of algal growth by iron deficiency in the Australian Subantarctic region. Geophys Res Lett 26(18):2865-2868

Smith WO, Harrison WG (1991) New production in polar regions: the role of environmental controls. Deep-Sea Res 38:1463-1479

Sommer U (1986) Nitrate and silicate competition among Antarctic phytoplankton. Mar Biol 91:345-351

Statham PJ (1985) The determination of dissolved manganese and cadmium in sea water at low nmol-1 concentrations by chelation and solvent extraction followed by electrothermal atomic absorption spectrometry. Anal Chim Acta 169:149-159

Tilzer MM, Elbrächter M, Gieskes WW, Beese B (1986) Lighttemperature interactions in the control of photosynthesis in Antarctic phytoplankton. Polar Biol 5:105-111

Tischner R, Lorenzen H (1981) Nitrate uptake and reduction in Chlorella. Characterisation of nitrate uptake in nitrate grown and nitrate-starved Chlorella sorokiniana. In: Bothe $\mathrm{H}$, Trebst A (eds) Biology of inorganic nitrogen and sulfur. Springer-Verlag, Berlin, p 252-259

Turner SM, Nightingale PD, Spokes LJ, Liddicoat MI, Liss PS (1996) Increased dimethyl sulphide concentrations in sea water from in situ enrichment. Nature 383:513-517

VanLeeuwe M, Scharek R, DeBaar H, DeJong J, Goeyens L (1997) Iron enrichment in the Southern Ocean: physiological responses of plankton communities. Deep-Sea Res part II Top Stud Oceanogr 44:189-207

Vanucci S, Bruni V (1999) Small nanoplankton and bacteria in the Western Ross Sea during sea-ice retreat (spring 1994). Polar Biol 22:311-321

Varela D, Harrison P (1999) Effect of ammonium utilization by Emiliania huxleyi, a coccolithophore from the oceanic northeastern Pacific. Mar Ecol Prog Ser 186:67-74

Wheeler PA, Kokkinakis SA (1990) Ammonium recycling limits nitrate use in oceanic subarctic Pacific. Limnol Oceanogr 35:1267-1278

Whitehouse MJ, Woodley VR (1987) Automated seawater nutrient analysis. British Antarctic Survey, Cambridge, UK (Spec Publ)

Whitehouse MJ, Priddle J, Symon C (1996) Seasonal and annual change in seawater temperature, salinity, nutrient and chlorophyll a distributions around South Georgia, South Atlantic. Deep-Sea Res 43:425-443

Whitehouse MJ, Priddle J, Brandon MA, Swanson C (1999) A comparison of chlorophyll/nutrient dynamics at two survey sites near South Georgia, and the potential role of planktonic nitrogen recycled by land-based predators. Limnol Oceanogr 44(6):1498-1508 